\title{
Second language attrition: Are different nouns equally likely to be lost?
}

\author{
HAMideh MAREFAT \\ AMIR ROUHSHAD \\ University of Tehran
}

Received: 15-01-07 / Accepted version: 13-02-07

ISSN: $1697-7467$

\begin{abstract}
This study aimed at investigating L2 attrition of vocabulary in adult Iranian learners of English at four different proficiency levels. A 40-item vocabulary test measured their productive and receptive vocabulary in and out of context for concrete and abstract nouns with different frequencies. After an interval of 3 months, subjects took the same test. The results revealed that there is no significant difference between the attrition rate of concrete and abstract nouns across different proficiency levels. Moreover, advanced learners who did not participate in classes and had no exposure to English throughout the 3 months interval demonstrated a significant amount of attrition in noncontextualized nouns. Besides, those learners who continued participating in English classes demonstrated attrition in receptive vocabulary but advanced non-continuing learners underwent attrition in productive vocabulary. Additionally, both continuing and noncontinuing learners except advanced ones underwent attrition in low-frequency nouns. These findings suggest that certain words are more vulnerable to attrition and that even learners who are still in the process of learning English are susceptible to it.

Key words: attrition, reception, production, contextualized vs. non-contextualized words, abstract vs. concrete words, high- vs. low-frequency words.
\end{abstract}

RESUMEN: Este estudio tiene como objeto investigar la pérdida de vocabulario en la segunda lengua en aprendices iraníes adultos de inglés que se encuentran en cuatro niveles distintos de competencia. Un test de 40 ítems medía su vocabulario (nombres concretos y abstractos con diferente frecuencia) a nivel de producción y recepción dentro y fuera de un contexto. Después de un intervalo de 3 meses, los sujetos hicieron el mismo test. Los resultados revelaron que no existe diferencia significativa entre el grado de pérdida de nombres concretos y abstractos en diferentes niveles de competencia. Además, los aprendices más aventajados que no participaron en clases ni estuvieron expuestos a la lengua inglesa durante los tres meses de intervalo mostraron una cantidad de pérdida significativa en nombres no contextualizados. Además, aquellos aprendices que continuaron asistiendo a clases de inglés mostraron una pérdida en recepción de vocabulario mientras que los aprendices avanzados sufrieron pérdidas en vocabulario de producción. Además, los dos grupos, los que siguieron las clases y los que no, a excepción de los de un nivel avanzado, sufrieron pérdidas en nombres de baja frecuencia. Estos hallazgos sugieren que ciertas palabras son más vulnerables ante esa pérdida y que incluso son susceptibles de ello los aprendices que están aún en el proceso de aprendizaje de la lengua inglesa. 
Palabras clave: pérdida de nivel, recepción, producción, palabras contextualizadas vs. no contextualizadas; nombres abstractos vs. concretos; palabras de alta y baja frecuencia.

\section{INTRODUCTION}

The study of language attrition is a newly emerging field whose conception occurred in 1980 in a conference at the University of Pennsylvania in which the theoretical basis of the field was discussed. Attrition refers to the non-pathological loss of a language in bilinguals; generally speaking, changes in the linguistic environment and termination of an instructional program may lead to attrition (Kopke \& Schmid, 2004). So, languages that we know might undergo attrition after a period of non-use to varying degrees. Since 1980, researchers have conducted various studies to obtain a deep knowledge of the process of attrition of a second or foreign language.

Language attrition is studied for two reasons. First, researchers have taken interest in knowing attrition processes and second, it has considerable pedagogical implications (Hansen, 2001a). Researchers have investigated the rate and amount of attrition in different areas or subskills of the attriting language and have come up with various results. Some have come up with significant loss of a language and some others have come up with slight loss. This variability in attrition studies has been attributed to duration of the period of disuse, original proficiency level, attitude, motivation and some other variables. Researchers have also been concerned with the effect of individual, social and affective factors on the rate and amount of attrition because the study of attrition cannot be separated from the social environment in which the individual's language is undergoing change.

\section{BAHRICK'S LANDMARK STUDY}

Bahrick (1984) carried out a landmark study in the field of second language attrition in which 773 subjects participated whose instruction took place from one to fifty years prior to the beginning of the study. These subjects were classified based on their level of training in Spanish. A number of tests were employed to measure the participant's reading, vocabulary, idiom recall and recognition. The results indicated that the amount of attrited knowledge within the first five years following training was constant regardless of participant's training level. In addition, the results of this study suggested that receptive vocabulary was much more immune to attrition than productive vocabulary. Bahrick (1984) also showed that the number of courses that students have passed has a positive correlation with the degree of maintenance

Neisser (1984) commented on the study of Bahrick (1984) saying that those participants who maintained knowledge of Spanish developed a "schema" or "structured system of relationships" for Spanish. Further, he proposed the "best connected, last forgotten" hypothesis. This hypothesis holds that those items of information that are well-connected to the schema are resistant to loss, whereas those items that are less connected to the schema are vulnerable to loss. 


\section{Attrition in ABSTRaCt AND CONCREte nOUnS}

De Groot and Keijzer (2000) suggested that concrete words are learned easily and forgotten late in comparison to abstract words. They put forward two theories explaining why concrete words are retained easily: Context availability theory and dual coding theory. The former holds that «concrete words may have more contexts associated with them because there is more information in their memory representation and this additional information may help anchor the new foreign language words» (De Groot and Keijzer, 2000, p. 18).

Likewise, dual coding theory holds that:

A concrete word would be represented in both the image system and the verbal system of the language to which it belonged, but an abstract word would be represented only in the verbal system of its language. Hence, the concrete word is more solidly embedded in the memory and would be less likely to be forgotten than the abstract word. (De Groot and Keijzer, 2000, p. 19)

Hence, concrete words are learned more easily and retained longer since they have more context associated with them and unlike abstract words they are represented both in the image system and verbal system of individual. Ghasemi Bagherabadi (2005) conducted a study on attrition of L2 English vocabulary in 25 Iranian high school students after a summer interval. The results of his study showed that the summer interval had a negative effect on student's knowledge of vocabulary; in his study attrition in verbs took place faster than in nouns and adjectives. Furthermore, in comparison to verbs and adjectives, nouns were least vulnerable to attrition. Moreover, vocabulary that students learned at the beginning of the academic year turned out to be more resistant to attrition than vocabulary that students learned near the end of the academic year. This is in accordance with Cohen $(1974,1986)$ who asserted that the vocabulary which is added most recently is most vulnerable to attrition. Ellis and Beaton (1993) remarked that «nouns are easiest to learn ...whereas verbs and adverbs are the most difficult to learn in foreign language vocabulary list-learning experiments» (p. 22). In addition children acquire nouns before other parts of speech. De Groot and Keijzer (2000) hypothesized that nouns are remembered better than verbs because they are easier to learn. So, according to regression hypothesis, verbs are more vulnerable to attrition than nouns because they are learned later. This is also supported by Ghasemi Bagherabadi (2005) since in his study nouns were least vulnerable to attrition.

\section{Attrition in Productive SKills AND ReCePtive SKILls}

Weltens and Grendel (1993) carried out a study using a lexical decision task to investigate lexical attrition among Dutch learners of French. The task focused on orthographic and semantic knowledge. They noticed that after a four year interval, attrition did not take place on receptive skills. Hence, they proposed that future studies should be most concerned with productive skills. In 1999, Yoshitomi showed that listening comprehension skill is immune to attrition even after one year of incubation. Further, the results of her study indicated that there might be a very slight deterioration in productive phonological skill within the first year 
of disuse. In the discussion section of her study, she indicated that Japanese returnees underwent little attrition in language subskills including verb morphology, articles and lexicon. Attrition was evident when returnees were required to combine language subskills for producing complex structures. Yoshitomi (1999) asserts:

This finding suggests that although the regression in the individual subskills of English is not considerable, the small degree of regression in various parts of their linguistic skills has a cumulative effect on the returnee's overall linguistic performance. As a result their increased difficulty in producing in English only becomes evident when they face a situation in which they must coordinate all the subskills simultaneously and spontaneously. (p.91)

The reason that the majority of researchers assert minimal attrition in returnees is that returnees make use of communicative strategies; this makes the investigation of attrition process difficult for researchers because for example when they pause more than they used to pause, their interlocutor or the researcher may judge that the returnee is merely thinking of what to say and not how to say something.

\section{Measuring instruments}

Nakuma (1997) stated that generally speaking attrition researchers employ two measuring instruments: (a) spontaneous speech data in the form of free conversation, story telling and the like, (b) tests. Although attrition researchers demonstrate more inclination to use the latter due to the convenience associated with it, they ought to consider the type of language ability being investigated; that is to say, for investigating linguistic attrition using tests is more appropriate and for investigating communicative competence using spontaneous speech data is more suitable. Thus, instruments for data elicitation must be selected with extreme care. Weltens (1989) chose an untimed test to elicit data from attriters of French in Netherlands. She noticed that although learners who suffered attrition said that their proficiency in French had deteriorated dramatically, their performance test hardly showed any sign of it. Accounting for this finding,

de Bot and Weltens (1995) remarked that attriters can find most of attrited words because they have enough time whereas when they are forced to find the right word in a limited time, they experience difficulty. This finding is also in accordance with the psychologists' belief that what is committed to memory cannot be expunged from it (Hansen, 2001a).

Yamgur (2004) stated that translation task is not appropriate for elicitation of data from attriters since it needs training and expertise. Even educated speakers need training to master translation. So, attrition studies which use translation for elicitation mistakenly show massive attrition. This is not due to deterioration of language but because they do not know how to translate. Hansen (2001b) remarked that one of the instruments which is also used in attrition studies for data elicitation is the can-do scale. Through this instrument attriters assess attrition in themselves. It has been used in many studies (Weltens, 1989; De Bot \& Lintsen, 1989; Wass, 1997; and Hansen, 2001b). Weltens (1989) investigated attrition of L2 French in young adult subjects. Attrition in these subjects was investigated both through can-do scale and 
tests. But there was a discrepancy between the results of tests and can-do scale. Tests hardly showed any sign of attrition but the can-do scale revealed considerable attrition. De Bot and Weltens (1995) suggested that

The discrepancy between (high) test result and low self-assessment may be due to attriter's awareness that their retrieval is slowed down when they are forced to come up with the right word in time, and so they (rightly) say that they have experienced language attrition. (p. 356)

\section{ThIS STUDY}

In many countries, a huge amount of budget is earmarked annually for the development of English proficiency of students. And, we have observed that the students attain this proficiency to varying degrees after one or two years of attending English classes. But when they stop using English for whatever reason, their English undergoes attrition as the time goes by. If we come to know which aspects of language undergo attrition within the first months of disuse, we can put more emphasis on them while students are in contact with the language. In this way we may be able to immunize them against attrition in those areas.

This study aims to provide insights into English L2 attrition by Iranian speakers. It examines the L2 attrition of concrete and abstract nouns in and out of context with different frequency levels in production vs. reception across different proficiency levels among those who continue and discontinue learning English. Hence, this study is unique since it investigates attrition not only in those who undergo a period of disuse but also in those foreign language learners who are in contact with the language.

\subsection{Research questions}

This study aims at investigating the following questions:

1. Is there any difference between the L2 attrition of concrete and abstract nouns in continuing and non-continuing students across different proficiency levels?

2. Is there any difference between the L2 attrition of contextualized and non-contextualized nouns in continuing and non-continuing students across different proficiency levels?

3. Is there any difference between the L2 attrition of production and reception of nouns in continuing and non-continuing students across different proficiency levels?

4. Is there any difference between the L2 attrition of nouns with high and low frequencies across different proficiency levels in continuing and non-continuing students?

\subsection{Method}

\subsubsection{Participants}

The participants in this study consisted of 40 adult Iranian male and female language learners who enrolled in English courses IM3, AD3, PR1, and IELTS at the Open Center for Artistic and Cultural Education of the University of Tehran in mixed classes during summer 
in 2005. The majority of the participants were students of the University of Tehran majoring in different fields including Law, Mathematics, Dentistry and Engineering. Their age range was between 18 and 25. The levels mentioned above, i.e., IM3, AD3, PR1 and IELTS, are equivalent to lower intermediate, intermediate, high intermediate and advanced levels respectively; there were 15 students in the lower intermediate level, 3 students in the intermediate level, 4 students in the upper intermediate level and 8 students in the advanced level.

In the second week of the fall semester, the staff in the Open Center for Artistic and Cultural Education of the University of Tehran were asked to provide the researchers with the telephone numbers of the students who had not enrolled for the fall semester. The record showed that 31 students had stopped coming to classes after the summer term but only 21 of them enjoyed the required feature for this study: they had lost contact with English and had no exposure to it after they stopped attending the classes. They formed the non-continuing group. The remaining 9 students continued coming to classes and they formed the continuing group.

\subsubsection{Instruments}

A 40-item vocabulary test including four types of items was developed. One type required participants to read one sentence which was provided for them and add a contextually appropriate sentence using the noun provided in parentheses. In this type, they were also required to write the Persian equivalent of the noun given to them. The second type required participants to write the English definitions of abstract and concrete nouns which were presented to them without any context. These two types measured their productive vocabulary in and out of context respectively. The third type asked participants to fill in the blanks with abstract and concrete nouns provided for them. The fourth type required them to match concrete and abstract nouns with their meanings which were provided for them in English. The last two types measured their receptive vocabulary in and out of context. For each level, 20 concrete and 20 abstract nouns were randomly extracted from the vocabulary books or texts that students read during the summer term in class. 10 concrete and 10 abstract nouns were randomly chosen for the productive section of the vocabulary test and the rest were used for the receptive section of the vocabulary test. The following table depicts the distribution of items.

Table 1. The distribution of the 40 vocabulary items across different conditions.

\begin{tabular}{|c|c|c|c|c|c|c|c|}
\hline \multicolumn{4}{|l|}{ Abstract } & \multicolumn{4}{|l|}{ Concrete } \\
\hline Contextual & & Non-contex & ualized & Contextual & & Non-contex & ualized \\
\hline $\begin{array}{l}\text { Production } \\
5 \text { items }\end{array}$ & $\begin{array}{l}\text { Reception } \\
5 \text { items }\end{array}$ & $\begin{array}{l}\text { Production } \\
5 \text { items }\end{array}$ & $\begin{array}{l}\text { Reception } \\
5 \text { items }\end{array}$ & $\begin{array}{l}\text { Production } \\
5 \text { items }\end{array}$ & $\begin{array}{l}\text { Reception } \\
5 \text { items }\end{array}$ & $\begin{array}{l}\text { Production } \\
5 \text { items }\end{array}$ & $\begin{array}{l}\text { Reception } \\
5 \text { items }\end{array}$ \\
\hline
\end{tabular}

This test was administered twice with a 3-month interval. The reliability of the test turned out to be .77 at stage 1 and .76 at stage 2 . As for the content validity of the test, the panel of experts at the Center agreed that the items in the test represent knowledge of vocabulary in English at the specified levels. The test for the advanced level included 3 high- 
frequency words and 37 low-frequency words. The test for the high intermediate level included 9 high-frequency words and 31 low-frequency words. The test for the intermediate level included 10 high-frequency words and 30 low-frequency words. The test for the low intermediate level included 9 high-frequency words and 30 low-frequency words. It should be noted that for the low intermediate vocabulary test, one item was dropped because of the experimenters' wrong choice of a word.

\subsubsection{Procedure}

Data for the present study was collected at two stages with an interval period of three months. Near the end of the summer term, at stage 1, all participants took the vocabulary test. The vocabulary test was administered during class time in one session. Then after a period of three months, at stage 2, the continuing group (those who attended the classes in the fall semester) took the same vocabulary test in class; and after making sure that the non-continuing students (those who for various reasons had not registered for the fall semester) had no contact with English language during the interval, the researchers gave them the vocabulary test. To find out the amount of attrition, the performance of participants at stage two was compared with their performance at stage one.

\subsubsection{Scoring system}

For scoring the vocabulary test, as far as the receptive section is concerned, if participants filled out the blanks and did the matching correctly, they were awarded a score of one for each. For scoring the productive section of the test that measured vocabulary knowledge out of context, if participants explained the meaning of the noun correctly or provided synonyms or antonyms, they got a score of one.

For scoring the productive section of the vocabulary test which measured vocabulary in context, for each item they were awarded a score of one for each of the following: writing the appropriate meaning, using the noun in an appropriate context and using the intended word as a noun (as instructed) in the English sentences.

So, at each stage for the vocabulary test, participants got scores for knowledge of the meaning of the words, use of the words in appropriate contexts, and use of the intended word specified in parentheses as nouns in English sentences.

\section{RESULTS}

Table 2 shows the descriptive statistics for continuing students' performance on abstract and concrete nouns. As the table shows, data are available only from high and low intermediate groups. Learners in the other groups did not continue participating in the classes. 
Table 2. Descriptive statistics for continuing students' performance on abstract and concrete nouns at both stages.

\begin{tabular}{clllll}
\hline Level & & Stage 1 & Stage 2 & \\
\hline & & Abstract & Concrete & Abstract & Concrete \\
& Mean & 14 & 13.75 & 14.25 & 13.25 \\
High intermediate & SD & 3.91 & 2.98 & 3.59 & 2.5 \\
& $\mathrm{~N}$ & 4 & 4 & 4 & 4 \\
& & & & & \\
Low intermediate & Mean & 11.9 & 12.65 & 12 & 12.80 \\
& SD & 1.34 & 1.66 & 1.224 & 2.84 \\
& $\mathrm{~N}$ & 5 & 5 & 5 & 5 \\
\hline
\end{tabular}

A repeated measures ANOVA was conducted for the abstract nouns. The results showed that neither stage $\left(\mathrm{F}_{(1,7)}=.039, \mathrm{p}>.05\right)$ nor proficiency level $\left(\mathrm{F}_{(1,7)}=2.003 . \mathrm{p}>.05\right)$ had a significant effect. It means that as far as students who continue their exposure to English are concerned, they do not undergo any attrition in abstract nouns. (In each of the analyses, only the main effect of stage is reported; the effect of proficiency and their interaction is reported only when they are significant.)

Next, another repeated measures ANOVA was conducted for concrete nouns. The results showed no attrition for continuing students (stage, $\mathrm{F}_{(1,7)}=.12$, $\mathrm{p}>.05$; proficiency, $\mathrm{F}_{(1,7)}=.23$, $\mathrm{p}>.05)$.

Thus far, we saw that there is no attrition for abstract and concrete nouns for continuing students. Now, let's see if attrition takes place in abstract and concrete nouns for those learners who have not continued studying English for various reasons. Descriptive statistics results are shown below in Table 3. As can be seen, data is available from three groups, i.e., advanced, intermediate and low intermediate groups.

Table 3. Descriptive statistics for non-continuing students' performance on abstract and concrete nouns at both stages.

\begin{tabular}{llllll}
\hline \multirow{2}{*}{ Level } & & Stage 1 & \multicolumn{3}{c}{ Stage 2 } \\
\cline { 3 - 6 } Advanced & Abstract & Concrete & Abstract & Concrete \\
& Mean & 16 & 16.5 & 14.75 & 14.12 \\
& $\mathrm{SD}$ & 2.61 & 1.77 & 3.24 & 3.090 \\
& $\mathrm{~N}$ & 8 & 8 & 8 & 8 \\
Intermediate & & & & & \\
& Mean & 13.66 & 15.66 & 15 & 13.33 \\
& $\mathrm{SD}$ & 1.527 & 3.214 & 2.64 & 3.214 \\
& $\mathrm{~N}$ & 3 & 3 & 3 & 3 \\
Low intermediate & & & & & \\
& $\mathrm{Mean}$ & 11.25 & 14.05 & 12.08 & 13.61 \\
& $\mathrm{SD}$ & 3.69 & 4.69 & 5 & 5.34 \\
& $\mathrm{~N}$ & 9 & 9 & 9 & 9 \\
\hline
\end{tabular}


A repeated measures ANOVA was conducted for abstract nouns. As the results showed, no attrition took place for abstract nouns even for the non-continuing students (stage, $\mathrm{F}_{(1,17)}$ $=.105, \mathrm{p}<.05)$.

What about concrete nouns? Results of the repeated measures ANOVA showed that there is no significant effect (stage, $\mathrm{F}_{(1,17)}=3.884, \mathrm{p}>.05$ ). But the significance level turned out to be .065 , which shows a trend of effect. In other words, at stage 2 , for concrete nouns there is a reduction in the performance of the students but not to a significant degree. As Table 3 above shows, for the advanced group, the mean for concrete nouns is 16.5 , but after a period of 3 months of non-exposure, it reduces to 14.125; for the intermediate level this mean decreases from 15.66 to 13.33 . And for the low intermediate level this mean runs down from 14.05 to 13.61 .

The second research question concerns the L2 attrition of contextualized and noncontextualized. Below is the table showing the descriptive statistic results in continuing students.

Table 4. Descriptive statistics for continuing students' performance on contextualized and non-contextualized nouns at both stages.

\begin{tabular}{llllll}
\hline Level & & Stage 1 & Stage 2 \\
\cline { 3 - 6 } & & Context & No context & Context & No context \\
High intermediate & Mean & 14 & 14.25 & 15.50 & 13 \\
& SD & 2.44 & 3.77 & 1.91 & 4.16 \\
& $\mathrm{~N}$ & 4 & 4 & 4 & 4 \\
& & & & & \\
Low intermediate & Mean & 13.80 & 11.15 & 15 & 10.60 \\
& SD & 2.28 & 1.60 & 1.22 & 2.75 \\
& $\mathrm{~N}$ & 5 & 5 & 5 & 5 \\
\hline
\end{tabular}

In order to see if there is any attrition for contextualized nouns across different proficiency levels, a repeated measures ANOVA was conducted. The results showed no significant effect (stage, $\left.\mathrm{F}_{(1,7)}=2.58, \mathrm{p}>.05\right)$.

At this stage another repeated measures ANOVA was conducted to see if attrition takes place for non-contextualized nouns. The results showed no significant effect for these nouns. Now it is time to see what the story is like for contextualized and non-contextualized nouns in students who do not continue learning English. The descriptive statistics table is provided below in Table 5 . 
Table 5. Descriptive statistics for non-continuing students' performance on contextualized and non-contextualized nouns at both stages.

\begin{tabular}{llllll}
\hline Level & & Stage 1 & \multicolumn{3}{l}{ Stage 2 } \\
\cline { 3 - 6 } Advanced & & Context & No context & Context & No context \\
& Mean & 15.75 & 16.87 & 13.75 & 14.12 \\
& $\mathrm{SD}$ & 2.12 & 1.80 & 2.91 & 3.52 \\
& $\mathrm{~N}$ & 8 & 8 & 8 & 8 \\
Intermediate & & & & & \\
& Mean & 17.33 & 12.66 & 16.66 & 12.33 \\
& $\mathrm{SD}$ & .577 & 3.21 & 2.88 & 1.52 \\
& $\mathrm{~N}$ & 3 & 3 & 3 & 3 \\
Low intermediate & & & & & \\
& $\mathrm{SD}$ & 4.52 & 3.16 & 5.43 & 4.85 \\
& $\mathrm{~N}$ & 9 & 9 & 9 & 9 \\
\hline
\end{tabular}

First, an attempt was made to see if there is any attrition of contextualized nouns for non-continuing students. The results showed that for contextualized nouns no attrition takes place. Both for stage and proficiency the $\mathrm{p}$ value is more than .05 (stage, $\mathrm{F}_{(1,17)}=1.53, \mathrm{p}>$ $.05)$.

But as for non-contextualized nouns, proficiency level showed a significant effect $\left(\mathrm{F}_{(2,17)}\right.$ $=3.5, \mathrm{p}<.05)$ but stage did not $\left(\mathrm{F}_{(1,17)}=1.48, \mathrm{p}>.05\right)$.

To answer the third research question, an attempt was made to see if there is any difference between the L2 attrition of production and reception of nouns in continuing and non-continuing students. The following table provides the descriptive statistics for both production and reception in continuing students.

Table 6. Descriptive statistics for continuing students' performance on production and reception of nouns at both stages.

\begin{tabular}{llllll}
\hline Level & & \multicolumn{3}{l}{ Stage 1 } & Stage 2 \\
\cline { 3 - 6 } & & Production & Reception & Production & Reception \\
High-intermediate & Mean & 13.25 & 16.75 & 11.75 & 15 \\
& SD & 5.12 & 2.06 & 3.30 & 1.41 \\
& $\mathrm{~N}$ & 4 & 4 & 4 & 4 \\
& & & & & \\
Low intermediate & Mean & 11.15 & 15.4 & 10.2 & 13.80 \\
& SD & 1.60 & 1.81 & 1.49 & 2.28 \\
& $\mathrm{~N}$ & 5 & 5 & 5 & 5 \\
\hline
\end{tabular}


The results showed no significant attrition for production of nouns (stage, $\mathrm{F}_{(1,7)}=3.28$, $\mathrm{p}>.05)$. Now let's see what happens to reception of nouns. The results showed that stage has a significant effect here $\left(\mathrm{F}_{(1,7)}=44.195, \mathrm{p}<.05\right)$. As Table 6 above shows, high intermediate students' mean is 16.75 at stage 1 ; but at stage 2, it is reduced to 15 . And for the low intermediate group, this mean is reduced from 15.4 to 13.80 . To see if this difference lies in high intermediate level or the low intermediate level, separate t-tests were conducted for each level. The results showed that this difference exists at both the high intermediate level $\left(\mathrm{t}_{(3)}\right.$ $=-3.65, \mathrm{p}=.035)$ and the low intermediate level $\left(\mathrm{t}_{(4)}=-6.532, \mathrm{p}=.003\right)$.

As for the non-continuing students, data is available from three groups: advanced, intermediate and low intermediate. Table 7 shows descriptive statistics for the three levels.

Table 7. Descriptive statistics for non-continuing students' performance on production and reception of nouns at both stages.

\begin{tabular}{llllll}
\hline Level & & Stage 1 & \multicolumn{3}{l}{ Stage 2 } \\
\cline { 3 - 6 } Advanced & & Production & Reception & Production & Reception \\
& Mean & 14.5 & 18.12 & 12 & 15.87 \\
& $\mathrm{SD}$ & 2.32 & 1.55 & 3.89 & 2.10 \\
& $\mathrm{~N}$ & 8 & 8 & 8 & 8 \\
Intermediate & & & & & \\
& $\mathrm{Mean}$ & 12 & 18 & 11 & 18 \\
& $\mathrm{SD}$ & 3 & 1.73 & 3.46 & 1 \\
& $\mathrm{~N}$ & 3 & 3 & 3 & 3 \\
Low intermediate & & & & & \\
& $\mathrm{SD}$ & 4.70 & 3.06 & 6.32 & 4.06 \\
& $\mathrm{~N}$ & 9 & 9 & 9 & 9 \\
\hline
\end{tabular}

As far as production is concerned stage has a significant effect $\left(\mathrm{F}_{(1,17)}=64.05, \mathrm{p}<.05\right)$.

In order to see if stage affects all the three levels or not, three t-tests were conducted comparing stage 1 scores with stage 2 scores at each level. The results showed that for advanced students this difference is significant $\left(\mathrm{t}_{(7)}=.180, \mathrm{p}<.05\right)$. But the difference was not significant for the intermediate level $\left(\mathrm{t}_{(2)}=1 \mathrm{p}=.423\right)$ nor for the low intermediate level $\left(\mathrm{t}_{(8)}=1.170, \mathrm{p}=.276\right)$.

The same analysis was conducted for the reception of nouns. Results indicated that there is no main effect for stage $\left(\mathrm{F}_{(1,17)}=.534, \mathrm{p}>.05\right)$.

To answer the last research question, the frequencies of the nouns selected for each proficiency level were determined. To see which type of words is more vulnerable to attrition at each level, the scores from stage 1 were compared with those of stage 2 for each proficiency level.

The following table shows descriptive statistics for continuing students' scores on highand low-frequency words across proficiency levels. 
Table 8. Continuing students' scores on high- and low-frequency words across proficiency levels.

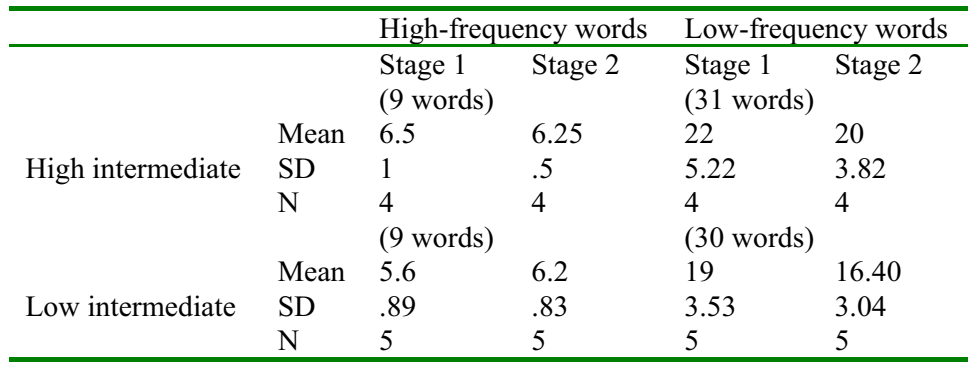

To see whether high-intermediate level students suffer attrition for high and low frequency words or not, t-tests were run. The results showed that no attrition took place for this level in high frequency words $\left(\mathrm{t}_{(3)}=.522, \mathrm{p}=.638\right)$; but attrition for low frequency words showed a trend $\left(\mathrm{t}_{(3)}=2.828, \mathrm{p}=.066\right)$ as the $\mathrm{p}$ value is very close to .05 .

As for the low-intermediate level, no attrition was observed for the high-frequency words $\left(\mathrm{t}_{(4)}=1.5, \mathrm{p}=.208\right)$; but for low frequency words a significant effect was observed $\left(\mathrm{t}_{(4)}=6.5, \mathrm{p}=.003\right)$.

Now let's go to the non-continuing students. Table 11 shows descriptive statistics for non-continuing students' scores on high- and low-frequency words across proficiency levels.

Table 9. Non-continuing students' scores on high- and low-frequency words across proficiency levels.

\begin{tabular}{|c|c|c|c|c|c|}
\hline & & \multicolumn{2}{|c|}{ High-frequency words } & \multicolumn{2}{|c|}{ Low-frequency words } \\
\hline & & $\begin{array}{l}\text { Stage } 1 \\
\text { (3 words) }\end{array}$ & Stage 2 & $\begin{array}{l}\text { Stage } 1 \\
\text { ( } 37 \text { words) }\end{array}$ & Stage 2 \\
\hline \multirow{3}{*}{ Advanced } & Mean & 2.5 & 2.25 & 30 & 25.62 \\
\hline & $\mathrm{SD}$ & .75 & .70 & 3.81 & 5.26 \\
\hline & $\mathrm{N}$ & $\begin{array}{l}8 \\
\text { (10 words) }\end{array}$ & 8 & $\begin{array}{l}8 \\
\text { (30 words) }\end{array}$ & 8 \\
\hline \multirow{3}{*}{ Intermediate } & Mean & 7.33 & 7 & 22.33 & 18 \\
\hline & SD & .57 & 2 & 2.88 & 2.64 \\
\hline & $\mathrm{N}$ & $\begin{array}{l}3 \\
\text { (9 words) }\end{array}$ & 3 & $\begin{array}{l}3 \\
\text { (30 words) }\end{array}$ & 3 \\
\hline \multirow{3}{*}{ Low intermediate } & Mean & 5.55 & 5.55 & 18.77 & 15.55 \\
\hline & $\mathrm{SD}$ & 1.5 & 2.45 & 5.42 & 4.58 \\
\hline & $\mathrm{N}$ & 9 & 9 & 9 & 9 \\
\hline
\end{tabular}

To see if at each level, frequency of the word has any effect on attrition or not, t-tests were run. As far as the advanced level students are concerned, neither high-frequency words 
$\left(\mathrm{t}_{(7)}=.683, \mathrm{p}=.510\right)$ nor low-frequency words $\left(\mathrm{t}_{(7)}=1.750, \mathrm{p}=.124\right)$ attrited. At the intermediate level, the high frequency words did not attrite $\left(\mathrm{t}_{(2)}=.378, \mathrm{p}=.742\right)$ but the low frequency words showed a significant attrition $\left(\mathrm{t}_{(2)}=13, \mathrm{p}=.006\right)$. The low intermediate group showed no attrition for high frequency words $\left(\mathrm{t}_{(8)}=.000, \mathrm{p}=1\right)$ but the low frequency words severely attrited $\left(\mathrm{t}_{(2)}=3.377, \mathrm{p}=.010\right)$.

\section{Results AND CONClusions}

The results of this study showed that neither continuing nor non-continuing students underwent any attrition in abstract and concrete nouns within three months interval. But, noncontinuing students showed a trend of attrition in concrete nouns which might turn out to be significant if the period of disuse continues. As can be seen, this is somewhat in contrast to literature in that concrete nouns have shown a trend of attrition but not abstract nouns; this might be due to high frequency of abstract nouns and low frequency of concrete nouns used in this study.

This study also shed some light on the effect of context on attrition of nouns; after a short period of non-exposure, knowledge of nouns attrites unless they are used in a context.

It was also revealed that attrition is not limited to those who lose exposure to L2; even continuing students undergo attrition in low-frequency nouns and also in their performance in reception of nouns. Additionally, as far as frequency is concerned, both continuing and non-continuing students demonstrated attrition in low frequency words. This is in harmony with literature.

Generally speaking, the findings of the present study shed some light on attrition of nouns across different proficiency levels for continuing and non-continuing students. In previous studies, the effect of context on attrition was not investigated, but this study showed the role of context in attrition. Additionally, this study showed that attrition is not limited to noncontinuing students and even continuing students might undergo attrition. Consistent with the results of previous studies, this study also showed that attrition in productive vocabulary surfaced faster than in receptive vocabulary. Moreover, the results are in harmony with the claim made by de Bot and Weltens (1991) that low-frequency words are more likely to be lost than high frequency words.

These findings have several pedagogical implications. Teachers should present new vocabulary in context and make students use them in context. As productive vocabulary is more vulnerable to attrition, teachers should put more emphasis on productive vocabulary so as to make these words resistant to attrition. Teachers had better identify low-frequency words in English course books and draw student's attention to them and provide students with more practice on low-frequency words. However, in order to conclusively claim these pedagogical implications, we need to undertake further investigation into the effect of focus on these items that are more vulnerable to attrition to see if such an emphasis will really make learners immune to attrition. 


\section{REFERENCES}

Bahrick, H. (1984). "Fifty years of second language attrition: Implications for programmatic research". The Modern Language Journal, 68: 105-118.

Cohen, A. (1974). "The Culver City Spanish Immersion Program: How does summer recess affect Spanish speaking ability?" Language Learning, 24(1): 55-68.

Cohen, A. (1986). "Forgetting foreign language vocabulary". In B. Weltens, K. de Bot \& T. van Els (Eds.), Language attrition in progress (143-158). Dordrecht, the Netehrlands: Foris.

de Bot, K. \& Weltens, B. (1991). "Recapitulation, regression, and language loss". In H.W. Seliger \& R.M. Vago (Eds.), First Language Attrition (pp. 31-52). Cambridge: Cambridge University Press.

de Bot, Kees \& Bert Weltens (1995). "Foreign language attrition". Annual Review of Applied Linguistics 15: 151-164.

de Bot, Kees \& Toke Lintsen (1989). "Perception of own language proficiency by elderly adults", ITL Review of Applied Linguistics, 83-84, 51-61.

de Groot, A. \& Keijzer R. (2000). "What is hard to learn is easy to forget: The roles of word concreteness, cognate status, and word frequency in foreign language learning and forgetting". Language Learning, 50(1): 1-56.

Ellis, N. \& Beaton A. (1993). "Psycholinguistic determinants of foreign language vocabulary learning". Language Learning, 43(4): 559-617.

Ghasemi Bagherabadi, M. (2005). L2 lexical attrition: Study of maintenance patterns after a break in instruction. Unpublished master thesis, University of Isfahan, Isfahan, Iran.

Hansen, L. (2001a). "Language attrition: The fate of the start". Annual Review of Applied Linguistics, 21: pp. 60-73.

Hansen, L. (2001b). "Language attrition in contexts of Japanese bilingualism". In M. Noguchi \& S. Fotos (Eds.), Studies in Japanese bilingualism (pp. 353-372). London: Multilingual Matters.

Kopke, B. \& Schmid, M. (2004). "Language attrition: The next phase". In Monika S. Schmid, B. Kopke, M. Keijzer and L. Weilemar (Eds.), First language attrition: Interdisciplinary perspectives on methodological issues (pp. 1-47). Amsterdam: John Benjamins.

Nakuma, C. (1997). "Cleaning up spontaneous speech for use in L2 attrition research: A proposal". Journal of Multilingual and Multicultural Development, 18: 135-144.

Neisser, U. (1984). "Interpreting Harry Bahrick's discovery: What confers immunity against forgetting?" Journal of Experimental Psychology: General, 113(1): 32-35.

Waas, Margit (1997). "First language loss: Reflex responses, repartee and sound symbolism". Language Problems and Language Planning, 21/1.

Weltens, B. (1989). The attrition of French as a foreign language. Dordrecht: Foris Publications.

Weltens, B., \& Grendel, M. (1993). “Attrition of vocabulary knowledge”. In R. Schreuder \& B. Weltens (Eds.), The bilingual lexicon. (pp. 135-156). Amsterdam: John Benjamin.

Yamgur, K. (2004). "Issues in finding the appropriate methodology in language attrition research". In M. Schmid et al. (Eds.), First language attrition (pp. 133-164).

Yoshitomi, A. (1999). "On the loss of English as a second language by Japanese returnee children". In L. Hansen (Ed.). Second language attrition in Japanese contexts (pp. 80-111). New York: Oxford University Press. 